\title{
Bakom rösten. Den implicita författaren i jagberättelser
}

"Jagformen används ofta i litteraturen om och för unga vuxna för att ge dessa en röst, för att komma så nära inpå unga människors tankar och känslor som möjligt. Samtidigt uppstår det flera berättartekniska problem, då det alltid finns en klyfta mellan det berättande och det upplevande jaget." Maria Nikolajeva undersöker jagberättelsen ur ett maktteoretiskt perspektiv

"Narrative fiction is the only literary genre, as well as the only kind of narrative, in which the unspoken thoughts, feelings, perceptions of a person other than the speaker can be portrayed" (Cohn 1978, 7). Denna genomskinlighet hos fiktiva personer jämfört med levande människor har ofta lyfts fram som den främsta attraktionen med skönlitteratur: som läsare kan vi träda in i andra människors tankar och känslor på ett sätt som är helt omöjligt i verkligheten. Vi kan ta del av deras åsikter och övertygelser, deras rädsla och deras hopp, deras mest hemlighetsfulla drömmar och begär. Det gäller inte minst jagformen som alltid har varit dominerande i ungdomsromanen såväl klassiska som moderna.

Även när en roman har självbiografisk bakgrund eller bygger på författarens egna barndomsminnen är berättelsen en fiktion, en (vuxen) författares föreställning om hur ungdomar upplever sitt liv och sin omgivning. Även om alla vuxna författare en gång varit unga betyder det inte automatiskt att de vill eller förmår att återge sina egna upplevelser. Jagformen används ofta i litteraturen om och för unga vuxna för att ge dessa en röst och för att komma så nära inpå unga människors tankar och känslor som möjligt. Samtidigt uppstår det flera berättartekniska problem, då det alltid finns en klyfta mellan det berättande och det upplevande jaget. Dessutom visar litteraturen för unga läsare en obalans mellan författarens strävan att närma sig den unga människan och det traditionella tvånget att uppfostra och predika. Den implicita författaren som döljer sig bakom det unga jaget blir därmed - eller åtminstone riskerar att bli - lika didaktisk som den konventionella opersonliga berättaren med pekpinnar och moralpredikan. Flera barnlitteraturforskare har påpekat att dold ideo- 
logi är både effektivare och lömskare än den uppenbara (se i första hand Hollindale 1988), och jagformen skapar ofta en illusion av en "äkta" ungdomlig röst, medan den i själva verket styrs av den vuxne i kulisserna. Detta eviga dilemma inom barn- och ungdomslitteraturen kan bäst undersökas med hjälp av olika maktteorier, framför allt heterologi ("discourse on the Other", Certeau 1986) i vilken den idag populära queer-teorin ingår som en beståndsdel. Queer-teorins centrala begrepp heteronormalitet kan i tillämpning på barnlitteratur översättas till vuxennormalitet, eller aetonormalitet (av latinskt aeto-, åldersrelaterat). Den vuxne som norm och barnet som avvikelse har styrt utformningen av barn- och ungdomslitteraturen från dess begynnelse fram till våra dagar (se Nikolajeva 2003b, 2005).

Föreställningen om att jagformen är svårare för unga läsare att ta till sig har dominerat synen på barn- och ungdomslitteraturen fram till relativt nyligen. Enligt läspsykologerna har unga människor och ibland även vuxna läsare utan avancerade läsvanor - problem med jagformen. Ett exempel som berör vuxna läsare är att man utan vidare sätter likhetstecken mellan författaren August Strindberg och jaget i hans verk. Det händer även med verk av Carina Rydberg, Kerstin Thorvall eller Maja Lundgren. Orsaken är i alla dessa fall svårigheter att uppfatta jaget som en fiktion. Förståelsen av fiktionalitet är emellertid den väsentligaste aspekten av läskompetens. Ungdomsförfattare som genom jagformen legitimerar trovärdigheten i sina verk kan lätt förleda läsarna att blanda ihop författaren och det fiktiva jaget, verklighet och konst. Detta händer ofta med böcker som Dave Pelzers Pojken som kallades Det (1993). Boken uppfattas som "bra" enbart eftersom den påstås vara verklighetsbaserad.

Samtidigt har jagformen även framhävts som ett fördelaktigt berättartekniskt grepp inom ungdomslitteraturen, med argumentet att läsaren får ta del av den unga berättarens innersta tankar, att en ung människas genuina erfarenhet avspeglas. Dessa vinster kan dock lätt vända sig till risker. Jagformen innebär inte automatiskt en djupdykning i berättarens inre liv; de allra flesta ungdomsromanerna i jagform, inte minst fiktiva dagböcker och brevromaner, fokuserar på de yttre händelserna och erbjuder i bästa fall berättarens kommentarer till dessa (se Nikolajeva 2008). Det är inte heller så att en autentisk ung röst ljuder bara för att en vuxen författare väljer en ung jagberättare. Tvärtom, när författare återger det de tror är en ung människas sätt att resonera, begränsad kognitiv förmåga, otillräcklig livserfarenhet och inte minst inkorrekt och fattigt språk kan det nästan kännas som om den vuxne författaren driver med den unga personens bristande färdigheter - ett typiskt fall av maktutövande. 


\section{Identifikationsfelslutet}

En annan ytterst viktig aspekt i den vuxna implicita författarens makt över såväl det fiktiva jaget som den unga läsaren är den så kalllade identifikationen. Identifikationsfelslutet (i analogi med nykritikens centrala begrepp "det intentionella felslutet", Wimsatt 1954) är kanske den starkaste vanföreställningen om barn- och ungdomslitteraturen och har odlats flitigt av både kritiker och läspedagoger. Det är vanligt i litteraturundervisningen att uppmana unga läsare att identifiera sig med någon person i texten, oftast huvudpersonen. En lärare kan ge uttryck till detta genom att ställa frågan: "Vem skulle du vilja vara i denna bok?" Barnlitteraturkritiker förespråkar gärna texter som erbjuder tydliga identifikationsobjekt. Detta synsätt avslöjar en förvånansvärd inkonsekvens mellan litteraturvetenskap och litteraturpedagogik. Övertygelsen om att unga läsare nödvändigtvis måste inta en fiktiv persons subjektposition är dock grundlös och hindrar faktiskt utvecklingen till en mogen läsare. ${ }^{1}$

Modern litteraturvetenskap, särskilt med inriktning på narratologi och receptionsteori, understryker vikten av läsarens förmåga att frigöra sig från de litterära personernas subjektposition, för att kunna bedöma och över huvud taget förstå dem (se t ex Stephens 1992, 47-83). Denna förmåga förstärker den kompetenta läsarens ideologiska och estetiska upplevelse av texten. Intressant nog förekommer identifikationstvånget sällan, om någonsin, i bedömningen av vuxenlitteratur. Hur skulle vi kunna läsa Dostojevskij om vi identifierade oss med Raskolnikov? Hur skulle vi kunna uppleva Shakespeare om vi identifierade oss med kung Lear? Hur skulle vi kunna njuta av Kafkas ironi om vi identifierade oss med Gregor Samsa? Varför läser man däremot ibland i barnboksrecensioner någonting i stil med: "Det här är en mycket bra bok eftersom det är lätt att identifiera sig med huvudpersonen"? Det finns ingen empirisk forskning om hur och vid vilken ålder identifikationsfelslutet blir övervunnet, men unga läsare måste vara oerhört motståndskraftiga mot vuxnas tryck för att kunna skifta från objekt till subjekt, från det passiva godtagandet av den fasta subjektposition, som den implicita författaren tvingar på dem, till en oberoende och flexibel sådan. Antagligen är det många vuxna läsare som aldrig kommer så långt.

På samma sätt måste författaren som inte vill tvinga och förtrycka sina unga läsare utarbeta intrikata strategier för att förvilla identifikationsbesatta vuxna och för att bakom ryggen på dessa portvakter undergräva identifikationstvånget. De allra flesta barn- och ungdomsboksförfattare sitter förmodligen kvar i föreställningen om den oumbärliga identifikationen. Man sammanblandar då identifikation med igenkännande eller empati. Paradoxalt nog, för att uppleva em- 
pati måste läsaren frigöra sig från den fiktiva karaktären, på samma sätt som ett barn i verkligheten måste lära sig att avstå från solipsismen och börja samspela med andra individer. Det är därför ytterst viktigt att inse vilken makt en författare besitter att förstärka eller förstöra subjektpositioner och därmed att stödja eller förhindra den unga läsarens befrielse från identifikationstyranni.

Konflikten mellan litterära och pedagogiska synsätt avspeglas i själva terminologin. Läspedagogiken talar om identifikationsobjekt, underförstått läsarens passiva roll som följer det som texten tydligast erbjuder. Litteraturvetenskap understryker det läsande subjektet, läsaren som en aktiv deltagare i läsprocessen, som interagerar med texten, dock utan att anamma dess inbyggda ideologi. Skillnaden kan ytterligare belysas i Michails Bachtins termer, som monologisk gentemot dialogisk konstruktion av subjektpositionen (se McCallum 1999; Wilkie-Stibbs 2000). Vi framhäver gärna att vi vill lära unga människor att läsa kritiskt, men så länge vi uppmuntrar dem att bli objektifierade och styrda av den implicita författaren kan de knappast förväntas vara kritiska mot det som de matas med.

Det är här som jagformen blir särskilt farlig om den hanteras ovarsamt, men det är också här den blir en utmaning. Jag ska i det följande ge några exempel på hur en jagberättelse kan fungera som maktutövning eller tvärtom, ge makt till unga människor, såväl fiktiva karaktärer som verkliga läsare.

\section{Den implicita författarens makt}

Men först en snabb tillbakablick. En av de första - det är alltid farligt att säga den allra första - jagberättelserna om en ung människas upplevelser var Huckleberry Finns äventyr av Mark Twain (1884). Många uppfattar denna roman som en fortsättning på Tom Sawyers äventyr (1876) eftersom den har samma personer och miljö, men det finns en väsentlig skillnad. Den första boken är en typisk pojk- och äventyrsbok med bovjakt, skattsökande, rymning och diverse hyss. I Huckleberry Finn är det inte längre oskuldfulla lekar, utan frågor om liv och död, befrielse från de vuxnas förtryck, och inte minst etiska frågeställningar där samhällets förlegade normer står mot huvudpersonens samvete. Jagformen tillåter inte bara en redogörelse för de yttre händelserna, utan funderingar och självreflektioner. Viktigast är dock att jaget, en ung människa, inte kommer med några didaktiska påpekanden som var vanliga i dåtidens ungdomslitteratur och fortfarande är kännetecknande för den. Det står inte i klartext och går inte att räkna ut när Huck berättar sin historia i förhållande till när den ägde rum. Det är i alla händelser ingenting som tyder på att Huck berättar i efterhand, när han redan är vuxen eller till och med 
gammal, och därmed har en distans till händelserna. Med fiktionens förutsättningar berättar han allt eftersom händelserna utspelar sig, och som läsare får vi följa jagets etiska utveckling utan att han själv kommenterar den. Den ironiska nästintill hånfulla, didaktiska berättaren från Tom Sawyer har upplösts i Huckleberry Finn. Denna bok, som allmänt utpekas som föregångare och stilbildande för sentida ungdomsromanen, lyckas alltså med något som få efterträdare presterat: att skapa en engagerande gestalt som dock effektivt saboterar identifikationen. Den röst som författaren har gett sin jagberättare har makten att styra läsaren mot en oberoende subjektposition. Det innebär att läsaren i bästa fall kan se Hucks tillkortakommanden utan att någon vuxen i texten behöver utpeka dem, vilket alltför ofta är fallet i ungdomsromaner.

Det vanligaste är annars retrospektivt berättande där en vuxen ser tillbaka på sin ungdom med ålderns visdom och kan bedöma och fördöma sig själv, komma med förklaringar och kommentarer. En sådan utformning skiljer sig inte väsentligt från den konventionella didaktiska tredjepersonsberättelsen och tillåter den vuxnas totala makt över den unga. För att värna sig mot detta våld tillgriper läsaren sannolikt identifikationen, vilket är precis vad syftet med maktutövandet är. Läsaren känner sig lika liten, dum och hjälplös som den unga huvudpersonen.

Texten kan också blanda berättarens och personens diskurs, så att det blir svårt att avgöra ifall en utsaga kommer från det vuxna berättande jaget eller det unga upplevande jaget. En sådan text är naturligtvis mer krävande, och identifikationen försvåras. Denna blandning förekommer till exempel i Katherine Patersons Se bergen (1980) där en vuxen kvinna återvänder till sina tonår, troligtvis i egna minnen snarare än i uttalad berättelse. Det berättande jaget kommenterar sina missuppfattningar och felsteg när hon var ung, men försöker samtidigt att rättfärdiga dem; det är också möjligt att hon minns fel, har förträngt sina traumatiska upplevelser eller medvetet undanhåller en del av händelserna. Den implicita författaren använder i sådana fall den retrospektiva berättarrösten för att utöva makten gentemot den unga huvudpersonen, men döljer samtidigt detta genom att använda det upplevande jaget som fokalisator, det vill säga, skildrar händelserna genom personens ögon och medvetande.

Den implicita författarens makt blir mindre påtaglig när avståndet mellan berättelsens tid och berättandets tid krymper, vilket är fallet i sådana välkända exempel som J D Salingers Räddaren i nöden (1951), Gunnel Beckmans Tillträde till festen (1969), Aidan Chambers Dansa på min grav (1982), Peter Pohls Janne min vän (1985) eller Katarina 
Mazettis Det är slut mellan Gud och mig (1995). I några av romanerna synkroniseras tiden mot slutet, och berättaren smälter samman med personen. Här kan man anta att texten verkligen kommer så nära huvudpersonens inre som möjligt; berättaren förblir dock opålitlig. Dels är jagberättare opålitliga per definition eftersom denna berättarform förutsätter subjektiv återgivning av subjektiva upplevelser. Dels befinner sig berättare i de ovan nämnda romanerna i upprört och förvirrat tillstånd under berättandet: Holden sitter på mentalsjukhus efter ett psykiskt sammanbrott, Annika har precis fått sitt dödsbud, Hal och Linnea sörjer döda vänner, och Krille kommer till en rad skakande insikter.

Personlighetsklyvning kan dock vara mer konkret och komplicerad än avståndet i tiden mellan berättarjaget och det upplevande jaget. I Sonya Hartnetts Surrender (2005) återger två jagberättare samma historia antifoniskt, växelvis i vartannat kapitel, bokstavligen i dialog, där de kompletterar med händelser som den andre inte kunde ta del av och, kanske ännu viktigare, rättar varandras felaktiga slutsatser. Tiden oscillerar mellan då och nu, men ingetdera är tydligt avgränsat. Så småningom kan läsaren räkna ut att ett av de två jagen, den förvildade pojken och mordbrännaren Finnigan, inte finns, han är enbart den mentalt sjuke Gabriels fantasiprodukt. Finnigan är Gabriels mörka sida, till vilken han överför sina onda drömmar och plågsamma minnen. Berättelsens nu visar sig vara en kort tid innan Gabriel dör av självsvält; det är hans unga liv som skildras i osammanhängande bitar som alla pekar på misshandel och förnedring från föräldrarna. Den tvetydiga titeln syftar inte bara på huvudpersonens slutliga uppgivelse, utan även på namnet på hans hund, som fadern dödar på ett grymt sätt. Tillsammans med Finnigan blir hunden jagets plåga. Men när Gabriel äntligen är redo att öppna den del av sitt minne som rör dagen då han mördade föräldrarna är han inte längre i stånd att skilja mellan sina olika personligheter, mellan då och nu, mellan ljus och mörker. Det behöver inte påpekas att någon identifikation med detta jag är utesluten. Peter Pohl går ännu längre i sitt berättartekniska experimenterande i Nu heter jag Nirak (2007) där det berättande jaget är en fantasifigur medan huvudpersonen omnämns i tredjeperson. Även detta får en främmandegörande effekt.

\section{Otillförlitlig berättare}

Man skulle då kunna tro att simultant personligt berättande, där det inte finns någon klyfta mellan de två jagen, gör att den implicita 
författaren helt och hållet avstår från sin makt. Det är dock just den unga berättarens röst som på ett tydligt sätt illustrerar ungdomsromanens dilemma. När den implicita författaren försvinner blir istället unga läsare utan vägledning när det gäller förståelse av händelser och personer. Laura i Katarina Kieris Ingen grekisk gud, precis (2002) har ingen att vägleda henne - och inte heller läsaren har det - i försöken att begripa vad som pågår. Även om hon ibland förefaller alltför förnuftig i sina resonemang, vilket kan bero på att det ändå finns en implicit författares ideologi och didaktik bakom henne, är det i stort sett bara hennes omedelbara själstillstånd läsaren tar del av, utan att berättaren får tid att reflektera över såväl händelser som sina reaktioner. Texten uttrycker det med subtila medel, utan att berättaren egentligen säger någonting rakt ut. Eftersom det inte finns någon äldre och klokare berättarinstans har vi som läsare bara den unga huvudpersonens version av händelserna, inte ens filtrerad genom en retrospektiv blick.

Som berättare är Laura otillförlitlig inte för att hon försöker att presentera sig själv på ett fördelaktigt sätt, inte heller för att hon har glömt eller förträngt sina upplevelser, utan helt enkelt därför att hon saknar förmåga att sätta ord på sina känslor eller att tolka andra människors beteende. Det är ett enda kaos som vräks ut på boksidorna och läsaren får reda ut det tillsammans med huvudpersonen. Detta ställer förstås högre krav på läsaren jämfört med till exempel Se bergen, där utredande genomförs av en vuxen berättarröst. Det är verkligen lätt att "identifiera" sig med Laura, men det är inte det som är syftet. Meningen är inte att se med Lauras ögon, utan att genomskåda henne, precis som berättarperspektivet anbefaller i Dansa på min grav eller Janne, min vän. Karakteristiskt nog blir problemet mindre i Kieris Dansar Elias? Nej! (2004) där hon använder sig av en manlig jagberättare. Som vanligt vid crossvokalisering (berättartekniken när författaren använder sig av en jagberättare av motsatt kön, se Nikolajeva 2003a) undviker författaren att fördjupa sig för mycket i det upplevande jagets inre liv, förmodligen av försiktighet ty man saknar direkta erfarenheter av genusrelaterade känslor och synsätt. När Aidan Chambers försöker återge en ung kvinnas uppfattning av sin kropp i That is all (2005) är resultatet betydligt mindre övertygande, för att inte säga falskt, jämfört med hans tidigare ungdomsromaner med manliga jagberättare. Trots att berättaren tillskrivs ett kön "performerar" berättarrösten tvärtemot konventionen, det vill säga, pojken berättar på ett feminint sätt och flickan på ett maskulint. Än en gång tvingar den implicita författaren på ett visst beteende på personerna. 


\section{Att främmandegöra jaget}

Crossvokaliseringen kan dock fungera om berättandet $\mathrm{i}$ övrigt förutsätter en distans. Melvin Burgess Vild och vacker (2001) ligger närmast fantasy i sin framställning. I romanen förvandlas berättaren Sandra till en hund. Det är ett mycket effektivt sätt att förhindra identifikationen: jaget främmandegörs så till den grad att alla frågor om sannolikhet förefaller irrelevanta. Även om jaget behåller sitt mänskliga intellekt - som för övrigt degraderar mer och mer under bokens gång - och även om författaren inte anstränger sig för att låta språket avspegla jagets nya mentalitet, är själva situationen tillräckligt overklig för att läsaren ska fästa uppmärksamheten vid röstens trovärdighet. Med andra ord: eftersom läsaren saknar erfarenhet av en hunds "äkta" berättarröst får jaget både större auktoritet och tillförlitlighet. Den unga flickans eventuella underlägsenhet gentemot vuxna kompenseras genom den frihet som hon får genom metamorfosen; mer än så: huvudpersonen berövas inte sin karnevaliska makt mot berättelsens slut, utan blir tvärtom mer och mer nöjd och säker i sin nya tillvaro och söker inte längre något botemedel. Detta är emellertid enbart möjligt på grund av att den unga kvinnan förvandlas till ett djur, det vill säga en lägre varelse i hierarkin än en människa. Huvudpersonens förvandling och därmed rörelsen inom maktstrukturen blir således tvetydig. I barn/vuxen-hierarkin växer hon, blir självständig och stark. Man kan, om man så vill, tolka berättelsen helt symboliskt, som en skildring av en pubertetskris med frigörelsen från föräldrarna och den sexuella friheten som två viktiga komponenter. Man kan även tillämpa en indignerad feministisk tolkning och kritisera den manliga författarens förakt och rädsla för vilda och okontrollerbara kvinnor. I människa/djur-hierarkin får jaget en lägre ställning, men det passerar nästan oförmärkt, just på grund av att djurgestalten ger henne så mycket mer makt på andra plan. Eftersom Sandra förblir en hund erbjuds det ingen lösning, och hon återförs inte till den ursprungliga makthierarkin, vilket bara är möjligt därför att hon som hund inte utgör något hot mot det mansdominerande människosamhället. Det är svårt at bedöma den implicita författarens ställning eftersom det är så många faktorer som spelar in.

\section{Opålitlig berättare}

Som framgår tydligt är det få författare som lyckas överbrygga klyftan mellan den implicita författaren och den unga jagberättaren. Ett undantag, där rösten aldrig skorrar, är den belgiske författaren 
Bert Moeyarts Bare hands (1995). Skildringen av de yttre händelserna blandas i romanen med berättarens mentala process på ett ytterst skickligt sätt. Det börjar in medias res, utan att man får någon som helst bakgrund till personerna, inte heller miljön eller situationen. Beskrivningar och bakgrunden kommer i berättelser med mentalgestaltning från den implicita författaren (varför skulle jaget berätta för sig själv någonting som han vet?), så i det här fallet håller denne sig borta. Själva handlingen tar bara några timmar, kanske tar händelserna lika lång tid som att berätta dem. På så vis blir jagets upplevelse extremt intensiv, en blandning av rädsla, skam och hat. Någon distans mellan det berättande och det upplevande jaget finns inte, i alla fall inte från början. Istället skildras ett enda kritiskt ögonblick, en vändpunkt eller snarare vägskäl efter vilket den unga människan har blivit vuxen. Minsta detalj, som ljudet från spisen, understryker jagets fokuserade perception. Samtidigt, mot all förväntan, bidrar inte denna ihållande synvinkel till "identifikation", utan uppmanar tvärtom till ett ställningstagande.

På ytan och upp till en viss punkt ter sig berättelsen som en typisk pojkbok. Som Tom Sawyer och Huck Finn vågar sig Ward, jaget, och hans vän Bernie, in på fiendens territorium. Man kan nästan se dem som folksagohjältar som stiger in i jättens håla för att stjäla ett magiskt föremål. Pojkarna är dock inga sagohjältar, och det som börjar som ett oskyldigt pojkstreck utvecklas till någonting betydligt allvarligare. Jätten, grannen herr Bentjeman, monstret med en hand av plast, dödar Wards hund. Genom berättarens ögon framställs han som en genomgående ond och farlig människa. Men helt oväntat, halvvägs genom boken, avslöjar en minnesglimt att för bara sex dagar sedan, på julafton, satt herr Bentjeman vid bordet hemma hos Ward. Som läsare anar man att berättaren, medvetet eller omedvetet, undanhåller oss information. Den implicita författaren styr berättelsen så att läsaren släpper Wards subjektposition och börjar fundera själv, även om empatin finns kvar. Uppenbarligen befinner sig det upplevande jaget i ett själstillstånd där han är oförmögen att få fram sin självrannsakan utan måste förtränga sina minnen. Plötsligt blir det som inte sägs viktigare än det som sägs. Å ena sidan är vi som läsare i samförstånd med Ward, eftersom han är huvudpersonen och berättelsens subjekt som kämpar mot ondskan; å andra sidan känner vi oss, med en sådan totalt opålitlig berättare, inte bara osäkra, utan övergivna och kanske till och med svikna. Sakta, mening för mening med flera sidor emellan får vi veta varför Ward hatar monstret. För en kompetent läsare blir Hamlet-intertexten uppenbar, men även annars förstår man den faderlösa pojkens drama, hans konflikt 
med modern och moderns nya fästman som håller på att invadera huvudpersonens hittills trygga hem. Spänningen mellan pojken och mannen och deras ömsesidiga avsky framstår med stor skärpa, fast vi bara tar del av Wards version av händelser. Berättelsens komplexitet, berättarperspektivets precision och frånvaro av någon som helst lösning är de mest framträdande greppen för att underminera identifikationen. Wards omedgörlighet kan till och med göra att läsaren tycker illa om honom. För en mogen läsare ska detta dock på inget vis omöjliggöra läsningen.

\section{Den försvunna implicita författaren}

Mark Haddons Den besynnerliga händelsen med hunden om natten (2003) tar berättarens tvetydighet ytterligare ett steg. Jagberättaren, den femtonårige Christopher, har Aspergers syndrom. Tyvärr avslöjas det $i$ baksidestexten, medan jaget inte nämner det $i$ sin berättelse. Han är medveten om att han är annorlunda, men han gör inte mycket väsen av det. Som bekant är personer med Aspergers syndrom ofta extremt begåvade, men osäkra i sina sociala relationer och har problem med att uttrycka sig. Just det senare gör författarens uppdrag i boken nära omöjligt: hur kan man återge en Asperger-drabbad ung mans upplevelse när man bara har språket att göra det med? Mycket riktigt tillgriper texten ofta visuella medel. Till exempel vet Christopher att $: ;$ betyder ledsen och $(-)$ betyder lycklig. Han lär sig på detta enkla vis att läsa av andra människors ansikten och även uttrycka sina egna känslor för vilka han saknar ord. Han är däremot mycket uppmärksam och iakttar detaljer i sin omgivning som andra inte märker, eftersom allting är precis lika viktigt för honom. Till exempel när han ser en massa skyltar på en tågstation tar han in dem alla på en gång - normalt sorterar vi information omkring oss och väljer det som är relevant.

Människor med Aspergers syndrom behöver ordning och stränga rutiner för att klara av vardagen. När någonting oväntat inträffar i Christophers liv blir han förvirrad och hjälplös, till exempel när han hittar grannhunden Wellington död utanför sin grind och försöker förstå hur det kan ha hänt och varför. Hunden blir bara en förvarning om de mycket större omvälvningar som ska drabba Christopher, när han upptäcker att hans mor, som alla har tidigare sagt var död, lever och i själva verket har övergett honom. Han bestämmer sig för att uppsöka henne och företar en resa som innebär helt nya och konstiga uppgifter för honom, som att hitta till en tågstation, ta ut pengar från en bankomat, köpa biljett och hitta rätt tåg. Han löser varje problem 
genom att tänka och planera det noga. Han låtsas att han spelar ett dataspel som heter "Tåget till London" och han måste ta det steg för steg. Med oerhörd precision återger texten ett asperger-medvetande, någonting som förefaller omöjligt. Boken slutar med att Christopher mot alla odds klarar ett prov i avancerad matematik, och han avslutar sin berättelse med en optimistisk sammanfattning av sina äventyr. I denna roman har den implicita författaren försvunnit och en ung människas omedelbara och ytterst komplicerade upplevelse trätt fram. Det finns inget behov att utöva någon makt; det är just genom sin underlägsenhet som den unga huvudpersonen får makten. Är det därför som boken marknadsförs både som ungdomsbok och som vuxenbok med olika omslag, och i Sverige har getts ut som vuxenbok? Slutar ungdomslitteraturen vara ungdomslitteratur när vuxennormaliteten upphör?

PS När jag har skrivit färdigt denna artikel märkte jag att i tre av de diskuterade texterna dödas en hund, och i en förvandlas en flicka till en hund. Jag avstår från kommentarer om detta är en slump.

\section{Not}

1 Jag har presenterat argument kring identifikationsfelslutet i en rad konferensföredrag, till exempel Childhoods 2005, Oslo, 2005, the Grimm Award Lecture, Osaka, 2005 (publicerat i IICLO Bulletin 2006: 29) och Fifth Nordic Workshop for Children's Literature Research, Worcester, 2006. En längre uppsats är under tryckning i en volym redigerad av Michael Cadden vid Nebraska University Press.

\section{Bibliografi}

Beckman, Gunnel. Tillträde till festen. Stockholm: Bonnier, 1969.

Burgess, Melvin. Vild och vacker. Stockholm: Rabén \& Sjögren, 2002.

Certeau, Michel de. Heterologies: discourse on the Other. Minneapolis: University of Minnesota Press, 1986.

Chambers, Aidan. Dansa på min grav. Stockholm: AWE/Geber, 1983.

Chambers, Aidan. This is all. The pillow book of Cordelia Kenn. London: Bodley Head, 2005.

Cohn, Dorrit. Transparent minds: narrative modes for presenting consciousness in fiction. Princeton, N.J.: Princeton University Press, 1978.

Haddon, Mark. Den besynnerliga händelsen med hunden om natten. Stockholm: Wahlström \& Widstrand, 2003. 
Hartnett, Sonya. Surrender. Sydney: Penguin, 1995.

Hollindale, Peter. "Ideology and the children's book". Signal 55 (1988): 3-22.

Kieri, Katarina. Ingen grekisk gud, precis. Stockholm: Rabén \& Sjögren, 2002.

Kieri, Katarina. Dansar Elias? Nej! Stockholm: Rabén \& Sjögren, 2004.

Mazetti, Katarina. Det är slut mellan Gud och mig. Stockholm: Alfabeta, 1995.

McCallum, Robyn. Ideologies of identity in adolescent fiction: the dialogic construction of subjectivity. New York: Garland, 1999.

Moeyeart, Bart. Bare hands. Asherville, NC: Front Street, 1998.

Nikolajeva, Maria. "Crossvokalisering och subjektivitet: den performativa rösten i litteraturen". Tidskrift för litteraturvetenskap (2003) 1-2: 53-76 (a).

Nikolajeva, Maria. "Varför sover Pippi med fötterna på kudden? Queer, karneval och barnlitteratur". Bonniers litterära magasin (2003) 3: 26-29 (b).

Nikolajeva, Maria. "Børnelitteratur: kunst, pædagogik og magt". I På opdagelse i børnelitteraturen, red. Nina Christensen och Anna Karlskov Skyggebjerg. Höst, 2005, ss. 29-44.

Nikolajeva, Maria. "Det självutlämnande jaget: den fiktiva dagboken i barn- och ungdomslitteratur". I Barnlitteraturanalyser, red Maria Andersson och Elina Druker. Lund: Studentlitteratur, 2008, ss. 179-194.

Paterson, Katherine. Se bergen. Stockholm: Litteraturfrämjandet, 1986.

Pelzer, Dave. Pojken som kallades Det. Stockholm: Forum, 2001.

Pohl, Peter. Janne, min vän. Stockholm: AWE/Geber, 1985.

Pohl, Peter. Nu heter jag Nirak. Stockholm: Alfabeta, 2007.

Salinger, J. D. Räddaren i nöden. Stockholm: Bonnier, 1990.

Stephens, John. Language and ideology in children's fiction. London: Longman, 1992.

Twain, Mark. Tom Sawyers äventyr. Stockholm: Rabén \& Sjögren, 2002.

Twain, Mark. Huckleberry Finns äventyr. Stockholm: Rabén \& Sjögren, 2001.

Wilkie-Stibbs, Christine. The feminine subject in children's literature. New

York: Routledge, 2002.

Wimsatt, William K. och Monroe C. Beardsley. "The intentional fallacy." I

The verbal icon: studies in the meaning of poetry. London: Methuen, 1954.

Nyckelord: berättarteknik, makt (i litteraturen) 